\title{
THE GREAT DISCONNECT: Reconnecting the ACAdeMy to the Profession
}

\author{
DOUGLAS D. FERGUSON*
}

This article examines what the author calls "the great disconnect" between law schools and the profession. After a discussion of the purpose of law school and the current status of the academy and articling, the article traces the history of the relationship between law faculties and the profession over the past century. This relationship has, for the past 50 years, resulted in little connection between the academy and the profession. Recent efforts by the Federation of Law Societies of Canada to regulate curriculum have now made the relationship more important than ever.

The author looks at the effect the great disconnect has had on Canadian law schools and makes a number of recommendations on their future relationship with the profession, including institutional links with law societies and the Canadian Bar Association. Curriculum reform can also help bridge the great disconnect by implementing an integrated approach to legal education proposed by the Carnegie Foundation for the Advancement of Teaching, an approach that is being implemented in many law schools across the United States.
Cet article examine ce que l'auteur appelle «le grand fossé» entre les écoles de droit et la profession. Après une discussion sur la raison d'être des écoles de droit et l'état actuel de la formation juridique et des stages, l'article fait l'historique de la relation entre les facultés de droit et la profession au siècle dernier. Au cours des 50 dernières années, cette relation a résulté en seulement quelques liens entre la formation universitaire et la profession comme telle. Suite au récent effort de la Fédération des ordres professionnels de juristes au Canada de régler le programme, cette relation a pris plus d'importance que jamais auparavant.

L'auteur considère l'effet du grand fossé sur les écoles de droit canadiennes et fait plusieurs recommandations en ce qui concerne leur relation future avec la profession, incluant des liens institutionnels avec des ordres professionnels de juristes et l'Association du Barreau canadien. La réforme de la formation peut aussi aider à combler la lacune du grand fossé par la mise ouvre d'une approche intégrée à la formation juridique proposée par la Carnegie Foundation for the Advancement of Teaching, approche déjà adoptée dans plusieurs écoles de droit aux États-Unis.

\section{TABLE OF CONTENTS}

I. INTRODUCTION . . . . . . . . . . . . . . . . . . . . . . 820

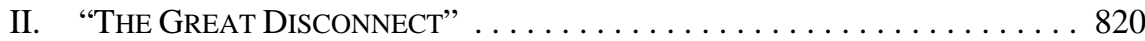

III. A BRIEF OUTLINE OF THE HISTORY OF

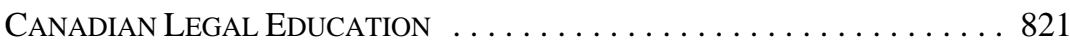

IV. The Relationship BetweEn LAW SCHOOLS AND the Profession . . . 823

V. The Pressures for Reform in LEgAl EdUCATION . . . . . . . . . . . . . 824

VI. BRIDGING THE DisCONNECT $\ldots \ldots \ldots \ldots \ldots \ldots \ldots \ldots \ldots \ldots \ldots$

A. RE-ESTABLISHING THE LiNKS BETWEeN

THE ACADEMY AND THE PROFESSION $\ldots \ldots \ldots \ldots \ldots \ldots \ldots \ldots \ldots$

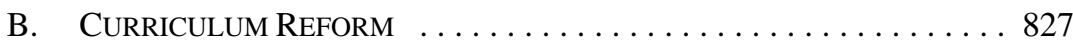

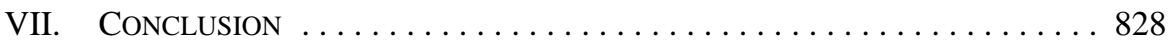




\section{INTRODUCTION}

For the first time in many decades, legal education is being examined with a critical eye in North America. Changes in our society, in the practice of law, and in technology have all combined to bring the issue to the forefront.

Law schools must adapt to keep pace. Merely preserving the status quo will only lead to change being thrust upon the academy. One of the issues that the academy must face is the fact that its graduates are entering a profession that is undergoing rapid change. This means that the relationship between the profession and the academy, which until now has been a distant one, must be strengthened.

The theme of this article is "the great disconnect" between law schools and the profession over the past 50 years. Its origins, as well as its effect on Canadian law schools will be examined.

Recommendations will be made on the future relationship between law schools and the profession. Recommendations will also be proposed on how the great disconnect can be bridged by implementing an integrated approach to legal education as proposed by the Carnegie Foundation for the Advancement of Teaching, an approach that is being implemented in many law schools across the United States. ${ }^{1}$

\section{II. “THE GREAT DISCONNECT”}

In debating the future of law school, one should start with a basic question: What is the purpose of law school? Some would suggest that the purpose of law school is to produce persons with law degrees who will have the analytical and critical thinking skills they need to be successful lawyers. Others would say that the purpose of law school is to produce lawyers who have the practical skills to be successful members of the profession. While lawyers need analytical and critical thinking skills, they need many other skills in the real world. Mediation, problem-solving, interviewing, advocacy, file management, time organization, and client relations are just some of the skills law graduates need in order to succeed after law school.

This is the first aspect of the great disconnect. Many law school faculty members have never practiced law, or did so only briefly. This is not a criticism; the academic system in our universities rewards faculty for focusing on research. There are no rewards or recognition for teaching practical skills. Law professors must play ball in order to succeed. They have little choice. In this sense, universities pull professors away from the profession. As a result, many are unable to impart the practical skills that law students need in private practice, and focus on the doctrinal side of law. Contrast this to medical schools, where a substantial part of a medical student's education is clinical and professors are active in their profession, looking after patients and working in the hospitals. By contrast, law students can go through three years of law school without ever having met a client, appeared in a real court, drafted 
a will, incorporated a company, or closed a real estate deal — the everyday activities that lawyers carry out in practice.

Some may respond by suggesting that the articling term was intended to teach these additional skills. However, articling is not necessarily the answer for three reasons: (1) lawyers are not teachers by profession; (2) articling programs vary in quality and the kinds of skills taught; and (3) with the pressures of the billable hour, lawyers do not spend as much time as they should on training and mentoring.

The future of articling has been called into question, particularly in Ontario, where increases in law school enrolment and an influx of law graduates from other countries (both Canadian and foreign born) has resulted in a serious shortage in articling positions. The Law Society of Upper Canada's (LSUC) proposed Law Practice Program (LPP) is intended as an option for those who cannot obtain an articling position or do not wish to do so. ${ }^{2}$ It is expected that the LPP will continue to stimulate debate on the future of articling, both in Ontario and the other provinces. To understand how matters got to this point one must undertake a brief tour of the history of legal education in Canada.

\section{A BRIEF OUTLINE OF THE HistORY of CANAdian LEgal Education}

For most of the 19th century, students were left largely on their own to study for their bar exams. ${ }^{3}$ They were apprenticed to a principal for a period of years. ${ }^{4}$ In Ontario, students were eventually required to attend lectures at Osgoode Hall, which became an established law school under the direct control of the LSUC. ${ }^{5}$ There were no university-based common law schools until the founding of the Dalhousie law school in $1883 .{ }^{6}$ This was followed by the establishment of faculties of law in the prairie provinces in the early 20th century. ${ }^{7}$

By the 1920s, a three year law degree (usually using the Harvard approach to some extent) with a professional orientation towards practice, became the norm to enter the Canadian bar admission process. ${ }^{8}$ Thus in both the US and Canada for the past century, law students have followed the same path with the same teaching methods before being called to the bar. The most significant difference between our two countries was the extra step of articling.

Osgoode Hall remained the outlier. In the late 19th and first part of the 20th century, Ontario law students spent part of their day attending lectures taught primarily by

2 “Law Practice Program,” online: The Law Society of Upper Canada <http://www.lsuc.on.ca/licensing process.aspx?id=2147497057>.

3 John PS McLaren, “The History of Legal Education in Common Law Canada” in Roy J Matas \& Deborah J McCawley, eds, Legal Education in Canada: Reports and Background Papers of a National Conference on Legal Education held in Winnipeg, Manitoba, October 23-26, 1985 (Montreal: Federation of Law Societies of Canada, 1987) 111 at 114.

$4 \quad$ Ibid at 116 .

Ibid at 117 .

Ibid at $120-21$.

Ibid at 122-23. See also W Wesley Pue, “Common Law Legal Education in Canada’s Age of Light, Soap and Water” (1995) 23 Man LJ 654 at 662-74. McLaren, ibid at 120-29; Pue, ibid at 664-65. 
practitioners, and the remainder of the day with a practitioner in his practice. ${ }^{9}$ The curriculum was more professionally, rather than academically, oriented.

Osgoode Hall was the sole degree-granting law school in Ontario until the late 1950s, and remained under the control of the LSUC during that time (Manitoba's law school was also heavily influenced by its law society). ${ }^{10}$ In 1957 the LSUC agreed to allow the creation of law schools in university settings, and their numbers quickly increased to total five in all, including Osgoode itself which migrated to York University. ${ }^{11}$ Other Canadian law schools sprang up in the ensuing decades, such as Calgary, Victoria, Moncton, and the McGill common law program. ${ }^{12}$

Why did legal education move from apprenticeship to the university setting? It was increasingly seen as a discipline suitable for systematic analysis and investigation. American universities such as Harvard and Columbia had created law faculties or legal studies departments. A key development was the case study method developed by Harvard Law dean Christopher Langdell in the 19th century. The obvious forum for such instruction was the university setting. ${ }^{13}$

In 1919, the Canadian Bar Association (CBA) formed a special committee to develop national standards for law schools in the common law provinces. ${ }^{14}$ It recommended a subject list, and the years in which they should be taught, but had no required core curriculum. It was seen as a compromise between the academic and the practical, and was voluntarily adopted by Canadian law schools. ${ }^{15}$

In 1969, the LSUC changed curriculum requirements to follow recommendations by the Ontario law deans, with seven core courses that had to be taken by students and 18 other courses that were to be offered. ${ }^{16}$ This provided law schools with flexibility in designing their curriculum.

The Deans proposed and the Society accepted a new regime, under which the schools would undertake to offer coverage in the twenty-three areas selected in 1957, with two additions, Conflicts and Labour Law. However, henceforward students would only be required to take seven core subjects, Civil Procedure, Constitutional Law, Contracts, Criminal Law and Procedure, Personal Property, Real Property and Torts. Moreover, in addition to the eighteen options which had to be offered, each school would be free to add other optional subjects to allow for some degree of specialization and the opportunity of acquiring new knowledge. The Deans did not see the scheme as revolutionizing curriculum selection. They assured the Law Society that a high proportion of available teaching resources would be dedicated to the twenty-five subjects. Moreover, they predicted that most students would find themselves taking instruction in that very range of subjects. ${ }^{17}$

McLaren, ibid at 116-17.

Ibid at 129-34; Pue, supra note 7 at 671.

McLaren, ibid at 132-34.

Ibid at $135-36$.

Ibid at 119-20.

Ibid at 124.

Ibid.

Ibid at 134 .

Ibid. 
The other significant development in the last 50 years has been the introduction of clinical legal education starting in the early 1970s, which is now found in every common law faculty except those in New Brunswick and the new faculty at Lakehead. ${ }^{18}$

For the past 40 years, law societies took a hands-off approach to the common law degree. Law deans and faculties understandably developed a sense of autonomy.

\section{The Relationship Between Law Schools And the Profession}

Harry Arthurs in a recent article, describes the relationship between law schools and the profession as the "relevant other." ${ }^{19}$ He goes on to point out that the universities eventually became a second "relevant other" and influenced law faculties to move in a more scholarly direction. ${ }^{20}$ The university system of recognizing research, as opposed to clinical innovations or practical skills training, took hold and sharpened the doctrinal focus. Over the past 40 to 50 years, law professors (as a whole) became more academically inclined, focusing on research in specialized areas. As Arthurs states, "legal academics began to produce scholarship that diverged considerably from the intellectual agenda and discursive conventions of the practising bar." ${ }^{21}$ In other words, we had two silos: law schools in one and the profession itself in another. This is the second aspect of the great disconnect.

For most of the past 40 years, the great disconnect was not obvious. Students flocked to law schools, graduated, and found jobs. There was no crisis, and therefore no reason to change. Arthurs correctly points out that “the profession seldom contested the academy's primacy in the design and delivery of legal education. Therefore, the academy had no reason to challenge the profession's policies relating to admission to practice."22 This period of détente ended in 2009 when the Federation of Law Societies of Canada (FLSC) approved a set of competencies with which law schools must comply with in order to have its students automatically approved to enter the bar admission process. ${ }^{23}$

Arthurs was critical of the unilateral nature of the actions of the FLSC and he questioned its authority to set these requirements. ${ }^{24}$ However, the FLSC did not act unilaterally. It consulted with the Council of Canadian Law Deans, and the final report of its task force acknowledged their assistance. ${ }^{25}$ Although the law deans were unable to speak with one voice, which may not be surprising considering there are over 20 law deans in Canada.

But this begs the question: if law societies do not have the power to regulate admission to the bar admission process, and by extension to the profession, then who does? And if law

Douglas D Ferguson, “Experiential Learning Programs in Canadian Law Schools” (Presentation delivered to the Federation of Law Societies of Canada, September 2012), [unpublished].

Harry Arthurs, “'Valour Rather Than Prudence’: Hard Times and Hard Choices for Canada’s Legal Academy” (2013) 76:1 Sask L Rev 73 at 76.

Ibid.

Ibid at 77.

Ibid at 81 [footnotes omitted].

Ibid.

Ibid at 81-83, 87.

Task Force on the Canadian Common Law Degree, Final Report, October 2009 (Federation of Law Societies of Canada, 2009), online: Federation of Law Societies <http://www.flsc.ca/_documents/ Common-Law-Degree-Report-C(1).pdf $>$ at 4. 
societies have the power to regulate admission to the profession, does not this power extend to setting minimum standards to do so? Recommendations on dealing with the tension between the academy and the profession will be made later in this article.

\section{The Pressures for Reform in LEgaL EDUCATION}

In recent years, the legal profession has started to undergo significant change in both the US and Canada. The articling crisis in Ontario is just one symptom of change. In the US, and to some extent in Canada, tuition fees are extremely high with a questionable job future. US law school applications are down significantly. Some large US law firms are downsizing. More and more middle class persons cannot afford to hire a lawyer for litigation. More large clients are not prepared to pay for junior lawyers to work on their files. Rules of professional conduct and record keeping are more complex than ever. Globalization, outsourcing, and other providers of legal services are encroaching into the profession. And perhaps most importantly, technology and the Internet have armed clients with information and knowledge they did not have before.

All of these factors and others, have come together to lead to the questioning of our legal education system. The most recent debate in the US was launched by the 2007 publication of Educating Lawyers by the Carnegie Foundation for the Advancement of Teaching, which examined a number of law schools across North America. ${ }^{26}$

The report made a number of observations, the most important of which was that law schools rely heavily on one way of teaching to accomplish the socialization process. ${ }^{27}$ The case-dialogue method has some strengths in teaching students to think like lawyers, but has some unintended consequences:

By contrast, the task of connecting these conclusions with the rich complexity of actual situations that involve full-dimensional people, let alone the job of thinking through the social consequences or ethical aspects of the conclusions, remains outside the [case-dialogue] method. Issues such as the social needs or matters of justice involved in cases do get attention in some case-dialogue classrooms, but these issues are almost always treated as addenda. Being told repeatedly that such matters fall, as they do, outside the precise and orderly "legal landscape," students often conclude that they are secondary to what really counts for success in law school — and in legal practice. In their all-consuming first year, students are told to set aside their desire for justice. They are warned not to let their moral concerns or compassion for the people in the cases they discuss cloud their legal analyses. $^{28}$

The Carnegie Foundation also found two significant limitations with legal education. The first was

the casual attention most law schools give to teaching students how to use legal thinking in the complexity of actual law practice. Unlike other professional education, most notably medical school, legal education 
typically pays relatively little attention to direct training in professional practice. The result is to prolong and reinforce the habits of thinking like a student rather than an apprentice practitioner. ${ }^{29}$

The second was "law schools' failure to complement the focus on skill in legal analyses with effective support for developing the ethical and social dimensions of the profession. Students need opportunities to learn about, reflect on, and practice the responsibilities of legal professionals."30

\section{The Foundation’s major recommendation was an integrated curriculum:}

To build on their strengths and address their shortcomings, law schools should offer an integrated, three-part curriculum: (1) the teaching of legal doctrine and analysis, which provides the basis for professional growth; (2) introduction to the several facets of practice included under the rubric of lawyering, leading to acting with responsibility for clients; and (3) exploration and assumption of the identity, values and dispositions consonant with the fundamental purposes of the legal profession.

[T] he teaching of legal analysis, while remaining central, should not stand alone as it does in so many schools. The teaching of legal doctrine needs to be fully integrated into the curriculum. It should extend beyond case-dialogue courses to become part of learning to "think like a lawyer" in practice settings. ${ }^{31}$

The Carnegie Report has triggered major curriculum reform in American law schools. For example, the School of Law at Washington and Lee University in Virginia now have a third year that is mainly experiential learning. ${ }^{32}$ Northeastern University in Boston has a co-op program with law students spending three months in class followed by three months in a placement. ${ }^{33}$ Even venerable Harvard now has a problem-solving course in first year, and has over 40 clinics. ${ }^{34}$ More radical proposals, such as cutting law school down to two years, are being debated. ${ }^{35}$

In Canada, the Carnegie Report has barely caused a ripple. Osgoode Hall has instituted a requirement to take an experiential learning course in order to graduate. ${ }^{36}$ More

$29 \quad$ Ibid at 188.

30 Ibid.

31 William M Sullivan et al, "Summary of the Findings and Recommendations from Educating Lawyers: Preparation for the Profession of Law," online: Carnegie Foundation for the Advancement of Teaching <http://www.carnegiefoundation.org/sites/default/files/publications/elibrary_pdf_632.pdf> at 8-9.

32 “About the JD Program at W\&L,” online: Washington and Lee University School of Law <http://www. law.wlu.edu/admissions/page.asp?pageid=311>.

33 "The incomparable co-op: Four full-time work experiences. Countless opportunities," online: Northeastern University School of Law <http://www.northeastern.edu/law/experience/co-op/index. html>.

34 “Problem Solving Workshop,” online: Harvard Law School <http://www.law.harvard.edu/academics/ registrar/winter-term/problem-solving-workshop.html>; “Clinical and Pro Bono Programs” online: Harvard Law School <http://www.law.harvard.edu/academics/clinical/index.html>.

35 See e.g. Peter Lattman, “Obama Says Law School Should Be Two, Not Three, Years,” The New York Times (23 August 2013) online: The New York Times <http://dealbook.nytimes.com/2013/08/23/ obama-says-law-school-should-be-two-years-not-three/>.

36 “The Osgoode Juris Doctor Program,” online: Osgoode Hall Law School <http://www.osgoode.yorku. ca/programs/jd-program>. 
significantly, the new law school at Lakehead will implement a Carnegie-type curriculum. ${ }^{37}$ However the remaining law schools have not taken any steps in this direction. They are showing little inclination to reform despite the changes happening in the profession.

\title{
VI. BRIDGING THE DISCONNECT
}

\section{A. Re-establishing the Links Between the Academy and the Profession}

\author{
I hear and I forget. \\ I see and I remember. \\ I do and I understand.
}

- Chinese proverb attributed to Confucius

If law schools are to produce graduates who can better serve their clients and the administration of justice in a changing world, law school curricula need to be aligned with the realities of the practice of law. Curricula also need to recognize the reality that articling often does not provide the necessary skills that students need.

Law schools rightfully speak of the need for academic independence. However, the legal academy cannot ignore the fact that unlike other faculties such as science or arts, it is graduating students who are about to enter a profession. This crucial fact calls for a partnership with those who govern admission to the profession - the law societies.

The silos need to come down between law schools and the profession. They need to come to an understanding on the knowledge and skills law students should have. Interaction between the academy and the profession will do this, and will create a spirit of trust and understanding on both sides.

To that end, I recommend the following:

(1) Law schools and the profession must be partners in legal education. With mutual trust and goodwill, they can agree on a curriculum that meets the requirements of the law societies while providing the freedom for the academy to innovate, produce first-rate scholarship, and provide unique courses.

(2) The partnership need not be limited to the Juris Doctor degree. There is no reason why law schools cannot also be partners in continuing professional development (CPD). This would have the added benefit of continuing contact and crosspollination between professors and practitioners.

(3) Law schools should be considered part of the profession and treated as such. For example, should law societies have special benchers representing the academy (whether voting or non-voting)? 37 “Integrated Practice Curriculum (IPC)," online: Lakehead University <https://www.lakeheadu.ca/
academics/departments/law/ipc>. 
(4) As mentioned earlier, a curriculum drafted by the CBA was followed by law schools for decades in the early 20th century. Continuous engagement between the CBA and the academy can only enhance understanding of the changes in the profession that need to be addressed by law schools. Law schools should play an active role in the CBA and its provincial branches. While the Ontario Bar Association has seats on its council for every law school, at best only two or three attend. The following recommendations would assist in building a strong relationship between the CBA and its branches on one side, and the academy on the other:

(a) law schools should ensure their representatives attend and report to faculty councils on the provincial council meetings;

(b) the CBA and its provincial branches should make a special effort to ensure that faculty members are invited more often to speak at CPD sessions;

(c) law schools should have an annual CBA Day to encourage students and faculty members to join and participate. National or local CBA, or branch executives, should regularly visit law schools to speak with faculty; and

(d) the CBA and its branches should make a serious effort to recruit faculty to sit on their standing committees where appropriate.

(5) Compared to the US, there is little Canadian academic research on legal education and legal practice. This should be encouraged by law faculties, and the CBA and law societies should assist with its funding.

\section{B. CURRICULUM REFORM}

In addition to establishing links between the academy and the profession, I recommend the following curriculum reforms:

(1) The FLSC and law schools, in consultation with the CBA, should determine the substantive law, practical skills, and ethics that law students should learn in law school, and which would be better learned during articling or upon being called to the bar.

(2) Law schools that intend to produce practitioners should make a Carnegie-type curriculum available to their students. There are many ways to do so, from an approach that lasts throughout all three years of law school, to a capstone dominated by experiential learning in third year.

(3) Experiential learning can take several forms: in-class simulations, placements or externships, and clinics. American schools rely heavily on externships, and Canadian schools can learn from their experience. 
(4) The costs of a Carnegie curriculum can be managed by law schools. For example, Washington and Lee's College of Law found that the first two years of its curriculum was largely unchanged. ${ }^{38}$ Experiential learning need not have high personnel costs. For example, some courses such as real estate law could have some classes taught by a practitioner, who could take students through an exercise in carrying out a real estate deal. Many would consider it an honour to teach a few classes and would do so on a volunteer basis, and it would have the added benefit of giving professors more time for research. For example, at Western University, a practitioner taught wills in the usual way with doctrinal lectures. A clinic lawyer volunteered to work with him to add a simulation of interviewing a client and drafting a will based upon the instructions given during the interview.

(5) Ontario law schools should consider offering the equivalent of the proposed Law Practice Program as an option in second and third year. This would, of course, require approval of the LSUC. It would mean that law graduates could start practicing immediately after passing their bar examinations, rather than $10+$ months later, after their articling term was completed. This would appeal to many graduates.

(6) The FLSC should be prepared to require a reasonable but significant level of experiential learning in setting out the requirements for the common law degree.

(7) Law schools could provide a specialized curriculum, with little or no experiential learning, for those students who do not intend to enter private practice. For example, those who wish to enter academia or those who wish to play a policy role in government.

\section{CONCLUSION}

In the next few years, Canadian law schools will be under pressure from three sources:

(1) The FLSC as regulator.

(2) The CBA representing the profession (in particular the Futures Initiative and its focus on legal education).

(3) The articling crisis in Ontario.

To cope with these pressures, law schools need to build a bridge to bring them closer to the profession. That bridge can be built through institutional links, but that is not enough. The key element is a Carnegie-type reform of curricula that will integrate doctrine with professionalism and practical skills, and will bring together faculty and practitioners. 
Leadership by law deans, law society heads, and CBA and branch presidents will be crucial to forming these new bonds. All parts of the academy and the profession must come to the understanding that together they are a key part of the Canadian justice system, and not separate independent players. There must be a cultural change in their thinking.

We are now at a critical point in the evolution of legal education in Canada. All stakeholders need to focus on legal education for the next while. If we do not get legal education right, the profession and the public will suffer the consequences for decades to come. If we do get it right, our profession will be strengthened, the public better served, and the rule of law sustained. 